\title{
Pengembangan LKS IPA Terpadu Berbasis Permainan Edukatif Tema Zat Aditif dan Zat Adiktif Untuk Siswa SMP
}

\author{
Tiani Sofia Cindy Seko ${ }^{*}$, Anneke T. Rondonuwu ${ }^{2}$ \\ ${ }^{1,2}$ Jurusan Pendidikan IPA, FMIPA, Universitas Negeri Manado \\ "e-mail: sekocindy@gmail.com
}

\begin{abstract}
Abstrak. Penerapan pembelajaran IPA terpadu harus memperhatikan sumber belajar, bahan ajar dan media belajar. Salah satu contoh bahan ajar adalah LKS. Proses pembelajaran IPA akan lebih bermakna apabila dalam proses pembelajarannya guru dapat menarik minat siswa untuk mempelajari IPA. LKS yang disertai permainan edukatif akan lebih memotivasi siswa untuk aktif dalam kegiatan pembelajaran. Penelitian ini bertujuan untuk mengembangkan LKS IPA terpadu berbasis permainan edukatif yang valid dan layak digunakan dalam proses pembelajaran dan untuk mengetahui respon guru dan peserta didik terhadap LKS IPA terpadu berbasis permainan edukatif tema zat aditif dan zat adiktif. Penelitian ini merupakan penelitian research and development. Model pengembangan yang digunakan adalah model ADDIE. Berdasarkan hasil uji coba validasi ahli materi dalam bentuk angket diperoleh hasil sebesar $86,86 \%$ dan hasil uji coba validasi ahli media dalam bentuk angket diperoleh hasil sebesar 49,05\%, persentase tersebut dalam kategori baik dan layak digunakan di lapangan. Kemudian uji coba kelompok kecil yang terdiri dari beberapa siswa kelas VIII SMP PGRI Tondegesan memperoleh hasil 92\% dan uji coba lapangan yang terdiri dari seluruh siswa kelas VIII SMP PGRI Tondegesan memperoleh hasil 90,5\%. Sehingga dapat disimpulkan bahwa pengembangan LKS IPA terpadu berbasis permainan edukatif layak digunakan dan dikembangkan di wilayah yang lebih luas.
\end{abstract}

Kata kunci: LKS IPA terpadu, permainan edukatif

\begin{abstract}
The application of integrated science learning must pay attention to learning resources, teaching materials and learning media. One example of teaching materials is LKS. The science learning process will be more meaningful if in the learning process the teacher can attract students' interest to learn science. LKS accompanied by educational games will motivate students to be more active in learning activities. This study aims to develop integrated science worksheets based on educational games that are valid and suitable for use in the learning process and to determine the responses of teachers and students to integrated science worksheets based on educational games with the theme of additives and addictive substances. This research is a research and development research. The development model used is the ADDIE model. Based on the results of the test of material expert validation in the form of a questionnaire, the results were $86.86 \%$ and the results of the media expert validation trial in the form of a questionnaire obtained the results of $49.05 \%$, the percentage was in the good category and suitable for use in the field. Then the small group trial consisting of several grade VIII students of SMP PGRI Tondegesan obtained 92\% results and the field trial consisting of all students of class VIII SMP PGRI Tondegesan obtained $90.5 \%$ results. So it can be concluded that the development of integrated science worksheets based on educational games is feasible to be used and developed in a wider area.
\end{abstract}

Keywords: integrated science worksheets, educational games 


\section{PENDAHULUAN}

Ilmu Pengetahuan Alam (IPA) merupakan rumpun ilmu yang memiliki karakter khusus yaitu mempelajari fenomena alam yang factual (faktual), baik berupa kenyataan (reality) atau kejadian (events) dan hubungan sebabakibat. Cabang ilmu yang termasuk rumpun IPA diantaranya biologi, kimia, fisika, astronomi/astrofisika, dan geologi. (Wisudawati dalam Kismawardani, Muharrami, \& Hadi, 2018). IPA merupakan ilmu mencari tahu tentang alam secara sistematis dan mengembangkan pemahaman serta penerapan konsep untuk dijadikan suatu produk yang menghasilkan, sehingga IPA bukan hanya kumpulan pengetahuan yang berupa fakta, konsep atau prinsip, melainkan suatu proses penemuan dan pengembangan (Depdiknas dalam Ramadhani \& Wahyuni, 2016).

Pembelajaran IPA diharapkan dapat memberikan pembelajaran secara utuh. IPA pada hakikatnya merupakan sebuah kumpulan pengetahuan (a body of knowledge), cara atau jalan berpikir ( $a$ way of thinking), dan cara untuk penyelidikan (a way of investigating). Pembelajaran IPA yang utuh bukan hanya pada pengetahuan saja, melainkan bagaimana peserta didik memperoleh pengetahuan tersebut. Proses pembelajaran IPA akan lebih bermakna apabila dalam proses pembelajarannya guru dapat menarik minat peserta didik mempelajari IPA. Menurut Trianto (2012), pembelajaran terpadu diawali dengan penentuan tema, karena dengan penentuan tema akan membantu siswa dalam beberapa aspek, diantaranya siswa yang bekerjasama dengan kelompoknya akan lebih bertanggung jawab, disiplin, dan mandiri, siswa akan lebih mudah mengingat dan siswa akan lebih termotivasi untuk belajar.

Penerapan pembelajaran IPA terpadu harus memperhatikan sumber belajar dan media belajar. Sumber belajar yang dimaksud adalah bahan ajar. Bahan ajar adalah segala bentuk bahan yang digunakan untuk membantu guru atau instruktur dalam melaksanakan kegiatan belajar mengajar di kelas (Kurniasih dalam Kismawardani, Muharrami, \& Hadi, 2018). Contoh dari bahan ajar berupa buku paket, modul, handout, model atau maket, bahan ajar interaktif, dan LKS.

Berdasarkan pengamatan di sekolah, bahan ajar yang digunakan adalah buku paket dan LKS. LKS merupakan lembaran-lembaran berisikan ringkasan materi dan petunjuk-petunjuk pelaksanaan tugas pembelajaran yang harus dikerjakan siswa, yang mengacu pada kompetensi yang harus dicapai (Prastowo dalam Kismawardani, Muharrami, \& Hadi, 2018). Lembar kerja adalah bahan dimana siswa diberikan langkah-langkah mengenai apa yang seharusnya dikerjakan siswa. LKS juga termasuk kegiatan yang memberikan siswa tanggung jawab utama dalam pembelajaran mereka sendiri. LKS merupakan perangkat pembelajaran yang berisi panduan bagi peserta didik untuk melakukan kegiatan secara terprogram. LKS bersifat simpel, serbaguna, dan relatif mudah untuk diterapkan. Penggunaan LKS akan memberikan kesempatan kepada peserta didik untuk ikut aktif dalam proses pembelajaran dan memberikan kesempatan penuh kepada siswa untuk mengungkapkan kemampuan dalam mengembangkan proses berpikirnya (Kurd an Akdeniz dalam Yıldırım, Kurt, \& Ayas, 2011).

Hasil penelitian Ylldırım, Kurt, \& Ayas (2011) yang menguji penggunaan LKS kimia tentang faktor-faktor yang mempengaruhi kesetimbangan kimia, menunjukkan bahwa LKS dapat membuat kegiatan belajar mengajar menjadi lebih terarah, selain itu juga LKS dapat meningkatkan aktivitas siswa dalam pembelajaran. LKS dapat membuat siswa menemukan sendiri konsep-konsep materi yang dipelajari.

LKS yang disertai permainan akan lebih memotivasi siswa untuk aktif dalam kegiatan pembelajaran. LKS berbasis permainan edukatif didalamnya berisi beberapa permainan yang bersifat mendidik. Permainan edukatif yaitu suatu kegiatan yang sangat menyenangkan dan bersifat mendidik sehingga dapat menumbuhkan 
kemampuan berpikir siswa (Rahayu, Mulyani, \& Miswadi, 2012).

Permainan edukatif bisa dilakukan secara individu atau berkelompok dengan harapan siswa akan lebih berminat dalam belajar karena pembelajaran yang biasanya berlangsung dirasa cukup membosankan (Ni'mah, 2013). Permainan memungkinkan adanya partisipasi aktif dari siswa untuk belajar, sehingga dapat membantu siswa merasa nyaman pada saat belajar dan merasa senang. Permainan juga dapat digunakan sebagai sarana untuk meningkatkan kerjasama antar siswa (Vegt dalam Kismawardani, Muharrami, \& Hadi, 2018). Permainan edukatif adalah sarana yang dapat merangsang aktivitas siswa untuk mempelajari sesuatu tanpa siswa menyadarinya, baik menggunakan teknologi modern maupun teknologi sederhana (Ismail dalam Rakhmanita, 2011). Hal yang sama diungkapkan juga oleh Torrente, Moreno-Ger, MartínezOrtiz, \& Fernandez-Manjon (2009), bahwa permainan akan membuat seseorang mengalami perubahan kondisi artinya siswa yang awalnya tidak fokus saat mengikuti pelajaran menjadi lebih fokus dan memiliki daya konsentrasi yang tinggi dalam mengerjakan tugasnya selama jangka waktu yang lama. Menurut Rifa (2012), manfaat permainan edukatif adalah untuk melatih kemampuan motorik, untuk melatih konsentrasi, untuk meningkatkan kemampuan sosialisasi, untuk melatih keterampilan bahasa dan untuk menambah wawasan.

Pengembangan LKS memerlukan persiapan yang matang dalam perencanaan materi dan tampilan untuk mendapatkan hasil yang optimal. Materi LKS harus diturunkan dari Standar Kompetensi (SK) dan Kompetensi Dasar (KD) yang telah ditetapkan, sedangkan desain LKS dikembangkan untuk memudahkan siswa berinteraksi dengan materi yang diberikan (Devi, Sofiraeni, \& Khairuddin, 2009).

Berdasarkan wawancara dengan beberapa peserta didik, peserta didik masih menganggap IPA sebagai pelajaran yang sulit, sehingga menjadikan IPA sebagai pelajaran kurang diminati oleh pesertan didik. Belum memadainya fasilitas penunjang untuk kegiatan pembelajaran semisal alat praktikum, yang membuat kurang efektifnya pembelajaran. Metode mengajar pendidik juga masih mengunakan metode ceramah, diskusi, dan memberikan banyak catatan yang menyebabkan kurang aktifnya peserta didik dalam pembelajaran.

Permasalahan - permasalahan tersebut mendorong peneliti untuk mengembangkan LKS IPA terpadu yang didalamnya terdapat beberapa jenis permainan. Pengembangan LKS IPA terpadu berbasis permainan edukatif ini dapat mendukung tercapainya tujuan pembelajaran IPA terpadu serta menimbulkan motivasi belajar siswa. Selain itu, dengan adanya pengembangan LKS ini bisa membantu guru dalam kegiatan pembelajaran. Tujuan dalam penelitian ini adalah diperoleh LKS IPA terpadu berbasis permainan edukatif yang dapat mendukung pembelajaran IPA terpadu serta siswa lebih aktif dalam pembelajaran.

\section{METODE PENELITIAN}

Metode penelitian yang digunakan dalam penelitian ini adalah penelitian pengembangan dengan model ADDIE dengan 5 tahapan yaitu tahap analysis (analisis), design (perancangan), development (pengembangan), implementation (implementasi), dan evaluation (evaluasi).

Tahap analisis (analysis). Kegiatan awal sebelum melakukan pengembangan terhadap produk LKS yaitu penelitian pendahuluan. Penelitian pendahuluan berupa observasi awal dalam kegiatan pembelajaran yang dilakukan dengan observasi sekolah sekaligus pemberian angket kepada peserta didik kelas VIII SMP PGRI Tondegesan.

Tahap perancangan produk awal (design). Setelah melakukan tahap analisis dari ditemukannya masalah pada tahap sebelumnya, maka kemudian peneliti melakukan pengkajian materi dan pengkajian konten pada LKS, lalu hasil dari analisis digunakan sebagai acuan dalam pengembangan LKS IPA terpadu berbasis permainan edukatif. 
Tahapan ini meliputi: 1) Pengkajian materi. Pada tahap ini ditentukan materi yang akan di sampaikan pada peserta didik. Materi yang pilih dalam penelitian ini adalah materi zat aditif dan zat adiktif, kemudian ditentukan indikator dari materi yang pilih sebagai ramburambu dalam pembuatan LKS yang diinginkan. 2) Perancangan produk. Setelah melakukan penetapan dan pemantapan materi, kemudian peneliti melakukan perencanaan awal dalam pembuatan produk berupa Lembar Kerja Siswa (LKS). LKS yang dirancang sesuai dengan kompetensi dasar, silabus dan berbasis permainan edukatif pada materi zat aditif dan zat adiktif kelas VIII SMP/MTs. Langkah pembuatan produk melalui beberapa tahapan, diantaranya: a) membuat judul, b) menentukan kompetensi inti dan kompetensi dasar yang digunakan, c) menentukan susunan materi, d) menentukan ukuran kertas, font, spasi, dan jenis huruf yang digunakan dalam penyusunan LKS, e) menentukan kombinasi warna yang menarik sebagai pendukung pembelajaran, f) menentukan struktur penulisan.

$\begin{array}{ccr}\text { Tahap } & \text { pengembangan } & \text { produk } \\ \text { (development). } & \text { Tujuan } & \text { tahap } \\ \text { pengembangan } & \text { adalah } & \text { untuk }\end{array}$
menghasilkan perangkat pembelajaran yang berupa LKS IPA terpadu berbasis permainan edukatif. Setelah dilakukan desain produk, kemudian dilakukan validasi desain yang terdiri dari validasi ahli. Validasi ini merupakan proses atau kegiatan untuk menilai apakah rancangan produk LKS IPA terpadu berbasis permainan edukatif sudah dikatakan efektif dan efesien dalam melatih pemahaman konsep peserta didik. Validasi ahli ini dilakukan oleh ahli materi dan ahli media dengan menggunakan instrumen validasi. Pada langkah ini akan didapatkan masukan dari validator sebagai bahan perbaikan LKS kedepannya sebelum diujikan kepada peserta didik.

Tahap implementasi produk (implementation). Uji coba produk dimaksudkan untuk mengumpulkan data yang dapat digunakan sebagai dasar untuk mengetahui daya tarik, tingkat kelayakan, dan efektivitas LKS IPA terpadu berbasis permainan edukatif. Uji coba produk dilakukan dengan cara: 1) Uji coba kelompok kecil (small group try-out). Uji coba kelompok kecil dilakukan kepada beberapa peserta didik di kelas VIII SMP PGRI Tondegesan. Peserta didik diminta untuk melihat produk yang dihasilkan, kemudian peserta didik diminta untuk memberikan penilaian terkait pengembangan LKS IPA terpadu berbasis permainan edukatif yang telah diperlihatkan sebelumnya. 2) Uji lapangan. Setelah LKS melewati uji coba kelompok kecil, kemudian LKS akan di uji lapangan. Uji lapangan akan dilakukan kepada seluruh peserta didik kelas VIII SMP PGRI Tondegesan. Peserta didik kemudian diminta untuk memberikan penilaian terhadap LKS IPA terpadu berbasis permainan edukatif yang telah dilihat.

Tahap revisi dan evaluasi produk (evaluation). Tahap revisi, setelah desain produk divalidasi oleh ahli materi, ahli media, dan dilanjutkan dengan uji coba produk, maka dapat diketahui kelemahan dari produk tersebut. Jika memang masih dalam kriteria layak digunakan dan terdapat saran selama uji coba, maka produk akan direvisi sesuai saran untuk menghasilkan produk yang lebih baik lagi. Tahap evaluasi, jika kelayakan menunjukkan pada kriteria cukup layak, maka produk revisi dan hasil perbaikan akan diuji cobakan kembali. Hasil uji coba ini apabila guru maupun peserta didik mengatakan bahwa produk baik dan menarik, maka LKS ini telah selesai dan menjadi produk akhir. Jika belum sempurna maka hasil uji coba ini dijadikan bahan perbaikan dan penyempurnaan LKS (dilakukan evaluasi) agar kemudian dapat diperbaiki menjadi LKS yang siap digunakan di sekolah.

Instrumen yang digunakan sebagai alat untuk memperoleh data yang diperlukan oleh peneliti dalam kegiatan penelitian yaitu lembar validasi berupa angket dengan skala Likert yang diisi oleh ahli media, ahli materi, guru/pendidik dan siswa/peserta didik. 


\section{HASIL DAN PEMBAHASAN}

\section{Perancangan LKS}

Proses pembuatan LKS ini dengan menggunakan basis permainan edukatif pada materi zat aditif dan zat adiktif. Langkah-langkah penyusunan desain produk LKS ni, diantaranya adalah menyesuaikan KI dan KD berdasarkan Kurikulum 2013. LKS ini menggunakan ukuran kertas yang digunakan adalah A4. Ukuran dan jenis font yang digunakan adalah 24 (Bernard MT Condensed), 14 (Bodoni MT), 13 (Bodoni MT), 12 (Times New Roman, Bodoni MT) dengan spasi 2,0. Adapun desain produk pengembangan LKS ini terdiri dari cover depan, kata pengantar, daftar isi, peta konsep, petunjuk penggunaan LKS, kompetensi inti dan kompetensi dasar, materi, LKS 1 zat aditif, LKS 2 zat adiktif, daftar pustaka.

\section{Kelayakan LKS}

Validasi produk dilakukan setelah pembuatan produk awal. Validasi dilakuan oleh 2 orang validator yaitu validasi ahli media dan validasi ahli materi.

Untuk validasi ahli materi, persentase (\%) validasi per aspek dalam validasi materi ini diperoleh dari jumlah jawaban responden $\left(\sum \mathrm{X}\right)$ per aspek dibagi jumlah nilai ideal $\left(\sum \mathrm{X}_{\mathrm{i}}\right)$ per aspek dikali dengan $100 \%$. Persentase rata-rata diperoleh dari jumlah persentase (\%) total semua aspek dibagi dengan banyaknya aspek. Setelah memperoleh hasilnya, diperoleh kriteria interpretasi yang telah ditentukan. Penilaian dari validator ahli media disajikan dalam Tabel 1.

Tabel 1. Rekapitulasi hasil validasi ahli media

\begin{tabular}{lllll}
\hline Aspek & $\left(\sum \mathrm{X}\right)$ & $\left(\sum X_{i}\right)$ & $(\%)$ & Kriteria \\
\hline Tampilan & 15 & 35 & 42,86 & Cukup \\
Konsistensi & 5 & 10 & 50 & Cukup \\
$\begin{array}{l}\text { Penggunaan } \\
\text { huruf }\end{array}$ & 10 & 20 & 50 & Cukup \\
$\begin{array}{l}\text { Kriteria } \\
\text { fisik }\end{array}$ & 8 & 15 & 53,33 & Cukup \\
\hline $\begin{array}{l}\text { Jumlah } \\
\text { total }\end{array}$ & 38 & 80 & 196,19 & \\
$\begin{array}{l}\text { Persentase } \\
\text { rata-rata }\end{array}$ & $49,05 \%$ & & \\
\hline Kriteria & Cukup & & \\
\hline
\end{tabular}

Berdasarkan Tabel 1, dapat dilihat bahwa hasil validasi ahli media, penilaian yang dicapai rata-rata adalah cukup dengan total penilain 38 dan persentase $49,05 \%$. Jumlah persentase validasi pada aspek tampilan sebesar $42,86 \%$ dengan kriteria cukup, pada aspek konsistensi sebesar 50\% dengan kriteria cukup, pada aspek penggunaan huruf sebesar $50 \%$ dengan kriteria cukup dan pada aspek kriteria fisik sebesar 53,33\% dengan kriteria cukup. Saran dari validator ahli media yaitu pada aspek tampilan, jarak penulisan pada judul LKS terlalu jauh, gambar-gambar yang ada pada LKS harus diperbesar, pada aspek konsistensi perbaiki footer dan pada aspek penggunaan huruf perbaiki ukuran font dan perbaiki jarak spasi. Melalui saran dari validator ahli media, maka produk direvisi agar produk menjadi lebih baik.

Untuk validasi ahli materi, persentase (\%) validasi per aspek dalam validasi materi ini diperoleh dari jumlah jawaban responden $\left(\sum \mathrm{X}\right)$ per aspek dibagi jumlah nilai ideal $\left(\sum \mathrm{X}_{\mathrm{i}}\right)$ per aspek dikali dengan $100 \%$. Persentase rata-rata diperoleh dari jumlah persentase (\%) total semua aspek dibagi dengan banyaknya aspek. Setelah memperoleh hasilnya, diperoleh kriteria interpretasi yang telah ditentukan. Penilaian dari validator ahli materi disajikan dalam Tabel 2.

Tabel 2. Rekapitulasi hasil validasi ahli materi

\begin{tabular}{|c|c|c|c|c|}
\hline Aspek & $\left(\sum X\right)$ & $\left(\sum X_{i}\right)$ & (\%) & Kriteria \\
\hline Kualitas Isi & 31 & 35 & 88,57 & $\begin{array}{l}\text { Sangat } \\
\text { layak }\end{array}$ \\
\hline Penyajian & 21 & 25 & 84 & $\begin{array}{l}\text { Sangat } \\
\text { layak }\end{array}$ \\
\hline Bahasa & 22 & 25 & 88 & $\begin{array}{l}\text { Sangat } \\
\text { layak }\end{array}$ \\
\hline $\begin{array}{l}\text { Jumlah } \\
\text { total }\end{array}$ & 74 & 85 & 260,57 & \\
\hline $\begin{array}{l}\text { Persentase } \\
\text { rata-rata }\end{array}$ & \multicolumn{4}{|c|}{$86,86 \%$} \\
\hline Kriteria & \multicolumn{4}{|c|}{ Sangat layak } \\
\hline
\end{tabular}

Berdasarkan Tabel 2, penilaian yang dicapai rata-rata adalah sangat layak dengan total penilaian 74 dan persentase $86,86 \%$. Adapun rincian persentasenya adalah jumlah persentase validasi pada aspek kualitas isi sebesar $88,57 \%$ dengan 
kriteria sangat layak, pada aspek penyajian mencapai persentase sebesar $84 \%$ dengan kriteria sangat layak dan pada aspek bahasa mencapai persentase sebesar 88\% dengan kriteria sangat layak. Saran dari validator ahli materi yaitu pada aspek kualitas isi tambahkan materi yang didapat di perguruan tinggi dan pada aspek penyajian teliti kembali peta konsep. Melalui beberapa saran dari validator, maka produk direvisi agar produk menjadi lebih baik.

\section{Kemenarikan LKS}

Setelah LKS dinyatakan layak untuk digunakan, maka dilakukan uji coba untuk mengetahui respon pendidik dan peserta didik agar diketahui tingkat kemenarikan LKS.

Untuk mengetahui respon pendidik, dilakukan penyebaran angket kepada pendidik bidang studi IPA di sekolah untuk menilai LKS berbasis permainan edukatif. Penilaian dilakukan oleh 1 (satu) orang pendidik bidang studi IPA. Hasil rekapitulasi penilaian yang diperoleh disajikan dalam Tabel 3.

Tabel 3. Rekapitulasi hasil respon pendidik

\begin{tabular}{|c|c|c|c|c|}
\hline Aspek & $\left(\sum X\right)$ & $\left(\sum X_{i}\right)$ & $(\%)$ & Kriteria \\
\hline Materi & 32 & 35 & 91,43 & $\begin{array}{l}\text { Sangat } \\
\text { menarik }\end{array}$ \\
\hline Penyajian & 34 & 35 & 97,14 & $\begin{array}{l}\text { Sangat } \\
\text { menarik }\end{array}$ \\
\hline $\begin{array}{l}\text { Permainan } \\
\text { edukatif }\end{array}$ & 19 & 20 & 95 & $\begin{array}{l}\text { Sangat } \\
\text { menarik }\end{array}$ \\
\hline Bahasa & 20 & 20 & 100 & $\begin{array}{l}\text { Sangat } \\
\text { menarik }\end{array}$ \\
\hline $\begin{array}{l}\text { Jumlah } \\
\text { total }\end{array}$ & 105 & 110 & 383,57 & \\
\hline $\begin{array}{l}\text { Persentase } \\
\text { rata-rata }\end{array}$ & \multicolumn{4}{|c|}{$95,89 \%$} \\
\hline Kriteria & \multicolumn{4}{|c|}{ Sangat menarik } \\
\hline
\end{tabular}

Berdasarkan Tabel 3, jumlah penilaian respon pendidik secara keseluruhan adalah 383,57 dengan rincian pada aspek materi persentase yang dicapai adalah 91,43\%, aspek penyajian mencapai $97,14 \%$, aspek permainan edukatif mencapai $95 \%$ dan aspek bahasa mencapai 100\%. Secara keseluruhan setiap aspek mendapatkan kriteria interpretasi sangat menarik. Dari hasil rekapitulasi hasil respon pendidik tersebut dapat disimpulkan bahwa LKS yang dikembangkan mencapai persentase rata-rata yaitu $95,89 \%$ dengan kriteria interpretasi sangat menarik. Jadi, dapat disimpulkan bahwa LKS sudah dapat digunakan sebagai bahan ajar di kelas tanpa perlu dilakukan revisi.

Hasil validasi oleh pendidik bidang studi mencakup 4 aspek penilaian dengan 22 pernyataan/pertanyaan. Hasil penilaian dari pendidik bidang studi mendapatkan nilai rata-rata persentase kemenarikan sebesar 95,89\%. Kriteria penilaiannya adalah sangat layak, dan responden tidak memberikan saran maupun komentar karena dinilai produk sudah sangat baik. Hal ini berarti sudah layak digunakan dalam pembelajaran. Setelah validasi dilakukan maka produk siap diuji coba.

Uji coba kelompok kecil dimaksudkan untuk menguji kemenarikan produk dengan skala responden yang lebih kecil. Uji coba kelompok kecil ini melibatkan 3 peserta didik yang dipilih secara acak. Uji coba kelompok kecil dilakukan dengan menjelaskan seputar LKS yang dikembangkan. Setelah peneliti menjelaskan produk, responden diberikan angket untuk menilai kemenarikan produk, selanjutnya peserta didik diminta untuk memberikan penilaian dengan cara mengisi angket. Hasil respon peserta didik terhadap LKS berbasis permainan edukatif disajikan dalam Tabel 4 .

Tabel 4. Hasil uji coba kelompok kecil peserta didik

\begin{tabular}{lll}
\hline No & Aspek & $\begin{array}{l}\text { Jumlah } \\
\text { persentase }\end{array}$ \\
\hline 1 & Materi & $91,7 \%$ \\
2 & Penyajian & $89,3 \%$ \\
3 & Permainan edukatif & $96,7 \%$ \\
4 & Bahasa & $90 \%$ \\
\hline Presentase rata-rata & $92 \%$ \\
\hline \multirow{2}{*}{ Kriteria interpretasi } & Sangat \\
& menarik \\
\hline
\end{tabular}

Berdasarkan Tabel 4, produk yang telah dikembangkan mencapai persentase rata-rata $92 \%$ dengan kriteria interpretasi yang dicapai yaitu sangat tinggi, hal ini 
berarti LKS yang dikembangkan oleh peneliti mempunyai kemenarikan sangat tinggi untuk digunakan sebagai alat bantu dalam kegiatan belajar khususnya pada materi zat aditif dan zat adiktif untuk kelas VIII SMP.

Hasil uji coba kelompok kecil, pada aspek materi mencapai persentase $91,7 \%$, aspek penyajian mencapai persentase $89,3 \%$, aspek permainan edukatif mencapai 96,7\% dam aspek bahasa 90\%. Keseluruhan jumlah persentase tersebut mencapai kriteria sangat tinggi. Sehingga, dapat disimpulkan bahwa menurut peserta didik, LKS yang dikembangkan sangat menarik.

Setelah melakukan uji coba kelompok kecil, kemudian produk diujikan kembali ke uji lapangan. Uji lapangan dilakukan untuk meyakinkan data dan mengetahui kemenarikan produk secara luas. Responden pada uji lapangan yaitu seluruh kelas VII SMP PGRI Tondegesan yang berjumlah 12 peserta didik. Hasil uji lapangan disajikan dalam Tabel 5.

Tabel 5. Hasil uji lapangan peserta didik

\begin{tabular}{lll}
\hline No & Aspek & $\begin{array}{l}\text { Jumlah } \\
\text { persentase }\end{array}$ \\
\hline 1 & Materi & $90 \%$ \\
2 & Penyajian & $93 \%$ \\
3 & Permainan edukatif & $89,2 \%$ \\
4 & Bahasa & $90 \%$ \\
\hline Presentase rata-rata & $92 \%$ \\
\hline \multirow{2}{*}{ Kriteria interpretasi } & Sangat \\
\end{tabular}

Berdasarkan Tabel 5, hasil yang didapat dari uji lapangan melalui angket peserta didik SMP PGRI Tondegesan, aspek materi persentase yang dicapai adalah 90\%, aspek penyajian mencapai 93\%, aspek permainan edukatif mencapai $89,2 \%$ dan aspek bahasa mencapai $90 \%$. Nilai persentase rata-ratanya adalah 90,5\% dengan mendaptkan kriteria interpretasi sangat menarik.

\section{KESIMPULAN}

Berdasarkan hasil penelitian dan pembahasan disimpulkan bahwa LKS IPA terpadu berbasis permainan edukatif tema zat aditif dan zat adiktif valid dan layak digunakan dalam proses pembelajaran IPA di SMP PGRI Tondegesan.

\section{DAFTAR PUSTAKA}

Devi, P. K., Sofiraeni, R., \& Khairuddin. (2009). Pengembangan perangkat pembelajaran untuk guru SMP. Bandung: PPPPTK IPA.

Kismawardani, A., Muharrami, L. K., \& Hadi, W. P. (2018). Pengembangan lembar kerja siswa berbasis permainan kartu edukatif pada pembelajaran IPA terpadu. Natural Science Education Research, 1(2), 206-213.

Ni'mah, L. H. (2013). Pengembangan LKS IPA terpadu berbasis permainan edukatif tema gerak tumbuhan dan faktor yang mempengaruhi untuk siswa SMP. Skripsi. Universitas Negeri Semarang.

Rahayu, P., Mulyani, S., \& Miswadi, S. S. (2012). Pengembangan pembelajaran IPA terpadu dengan menggunakan model pembelajaran problem base melalui lesson study. Jurnal Pendidikan IPA Indonesia, 1(1), 63-70.

Rakhmanita, M. D. (2011). Pengembangan education games materi organisasi kehidupan tingkat sel sebagai media pembelajaran siswa SMP. Skripsi. Universitas Negeri Semarang.

Ramadhani, N., \& Wahyuni, S. (2016). Pengembangan media educational game "Monopoli Fisika Asik (MOSIK)" pada mata pelajaran IPA di SMP. Jurnal Pembelajaran Fisika, 5(3), 235245.

Rifa, I. (2012). Koleksi games edukatif di dalam dan luar sekolah. Yogyakarta: Flashbooks.

Torrente, J., Moreno-Ger, P., MartínezOrtiz, I., \& Fernandez-Manjon, B. (2009). Integration and deployment of educational games in e-learning environments: The learning object model meets educational gaming. Journal of Educational Technology \& Society, 12(4), 359-371.

Trianto. (2012). Model pembelajaran terpadu konsep, strategi, dan implementasinya dalam Kurikulum 
Tingkat Satuan Pendidikan (KTSP). Jakarta: Bumi Aksara.

Yıldırım, N., Kurt, S., \& Ayas, A. (2011).

The effect of the worksheets on students' achievement in chemical equilibrium. Journal of Turkish Science Education, 8(3), 44-58. 